\title{
Tantric Corporeality Concept and Indian Modern Artist Jagdish Swaminathan
}

\author{
Lisa Kuzina \\ South Asian Art Department \\ State Institute for Art Studies \\ Moscow, Russia \\ E-mail:asilandco@yahoo.com
}

\begin{abstract}
This article investigates the trend in Indian modern art focused on the search for national identity in Indian traditional art. The early work of the Delhi artist Jagdish Swaminathan (1928-1994) and its connection with Tantric visual culture, a tradition spread throughout Indian subcontinent together with the Vaishnava and Shiva directions of Hinduism, Jainism and Buddhism since the 5th century AD, is considered. The inseparable connection of this tradition with bodily practices (meditation and yoga) and special ideas about the human and divine body, common to Indian religious and philosophical thought, specify the concept of corporeality, making it possible to reveal the features of a Tantric body reflected on the structure of a sacral object - yantra - as interpreted by Swaminathan. The paper considers the image of yantra, intrinsic to the theoretical and practical doctrines of salvation (tantras). J. Swaminathan's creative and theoretical program and its reflection in his early series "Color geometry of space" (1967) are analyzed. The research reveals how the artist reinterprets pictorial representation of European art, with the help of Tantra and its space and body concepts creating his own version of modernism, based on Indian artistic traditions and the specific symbolism of religious mysticism.
\end{abstract}

Keywords-Indian Modern Art; Jagdish Swaminathan; body; Tantra; corporeality; yantra; Neotantrism; geometry

\section{INTRODUCTION}

This article is aimed to analyze Jagdish Swaminathan's early painting through the perspective of the corporeality concept, which is specifically refracted in Tantrism. Despite the fact that Tantric imagery manifested itself in Swaminathan's painting rather as an interpretation: it is quite far from the reproduction of classical Tantric diagrams (unlike, for example, the ones by S.H. Raza, or Santosh, whose works are compositionally closer to yantras of different types, for example of the kāmakalā ${ }^{1}$ type); nevertheless, in his works on theory of art Swaminathan articulated the connection of his art with Tantric thought.

To analyze the issue of the ideas about a body, which served as a source of Swaminathan's imagery, it is necessary to regard the named ideas and tier representations, namely,

kāmakalā — a diagram symbolizing the sexual union of the god Śiva and the goddess Śakti. the peculiarities of the visual culture formed on the basis of the religious-philosophical tradition.

\section{TANTRIC VisUAL CULTURE AND CORPOREALITY CONCEPT}

It is worth explaining that the Tantric tradition is usually understood as various teachings based on literary texts $\operatorname{tantras}^{2}$ (but also āgamas 'tradition' or samhitā 'collection') describing the way to achieve liberation (mokșa, mukti) in this life and to obtain the status of the liberated (jīvanmukta). As a mystical branch of Hinduism, Tantra preaches an "accelerated" liberation or an easier and faster way to reach it in the unfavorable era of kali-yuga. Different ways of Hinduism are compared by Sergei Pakhomov, a Tantric philosophy scholar, with various genres of cinema: "Like a two-hour film sufficiently illuminating the events that could be stretched into many episodes, Tantra suggests compressing the process of acquiring moksa to as short a time as possible within one human life" [3].

The text of almost any tantra develops on the mandala principle (its composition can be called mandalic) and is closely related to its visual form. According to an Indian culture scholar and linguist, Tatyana Ya. Yelizarenkova, the emergence of hymns and liturgical texts was associated with the notion that the vision of truth appears before a rși 'sage' in the form of a static picture and only then it is recorded, clothed in the canonical form [4]. 


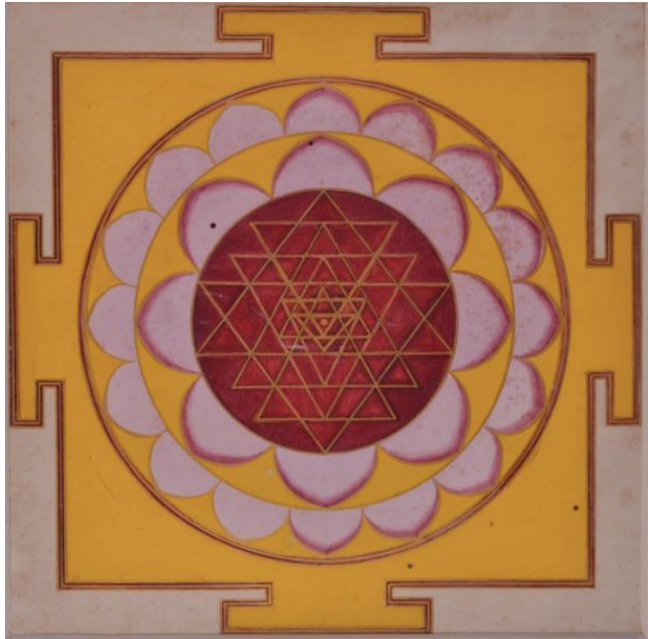

Fig. 1. Śriyantra (Śricakra).

In the tantra chapters on the description of meditative practice, one of the main images is cakra 'a circle'. Cakras constitute a greater symbolic construction, which should be represented by the adept as a centric form, developing from the center to the edges and vice versa. This visualization is associated with a sacred object - an image of a deity, and, more precisely, the Goddess - the female aspect of the god Siva. This meditative practice is called bhāvanā ('becoming' 'coming into existence') and is defined as the awakening of the deity's image in the mind, in other words, representing it as an object. Usually the specific geometric form (cakras) that the divine energy receives is described in detail. Thus, cakras connect with certain aspects of the deity and like disks are strung on a single axis, which rests in the central hub or kha (Sanskrit 'the void for the axle in the hub of a wheel').

In the Tantric tradition, it is believed that the universe exists because it is claimed to be the supreme deity, which is the Word $^{3}$ itself. The word (vāc) in Indian culture is closely related to a visual or sound image that can precede it and in which the truth appears to the initiated person. As the word has a creative cosmic power, so it is obvious that the main structure, on which the concept of the Tantric universe is based, is the Sanskrit alphabet, devanāgarī ('(writings) of the city of the gods'), manifested bodily in the sound of the sacred syllables of the Bīja-mantras, and in its totality it appears as the mother goddess, Mātrikā.

For example, in Cakrasamketa of tantric text Yoginīhrdaya - the chapter where śricakra in "Fig. 1" is described $^{4}$ - it is argued that the letters denoting vowels "from A to bindu" are the bodies of three energy-goddesses Vāmā, Jyesthā, and Raudrī, which are aspects of the main yoginī, or śakti [5]. These vowels together with consonants

The Identical relation of the higher deity and the Word, sounding in the body of the adept, is a sign of the non-dualistic direction of Shaivism. To this type of teachings the tantra Yoginīhrdaya ('The Heart of the Yoginī') adjoins.

Cakrasamketa 'co-existence of cakras' is a part of Yoginīhrdaya, where the cosmic process of the emergence of cakras, or evolvement of yantra is consistently described. This process of imagining yantra is called bhāvanā, a special meditation, connected with the make-up of the object.

form words serving as mantras. Four ślokas (36-40) of Yogininrdaya, its part illustrates the image of the Goddess, which is to unfold before him in meditation [6]:

ātmanạ̣ sphuranam paśyed yadā sā paramā kalā /

ambikārūpam apannā parā vāk samudīritā //36//

bījabhāvasthitam sphuṭīkartum yadonmukh̄̄ / vāmā viśvasya vamanād
aṅkuśākāratām gatā //37//

icchāśaktis tadā paśyantīvapuṣā sthitā / jñānaśaktis thatā jyeșthā madhyamā vāg udīitā //38//

rjurekhāmay $\overline{1}$ prathitavigrahā /

tatsamhṛtidaśāyām tu baindavam rūpam àsthitā //39//

pratyāvṛttikramenaivam vapur ujjvalā /

kriyāśaktis tu raudrīyam vaikharī viśvavigrahā //40/

[word], appearing as the universe. //40//

These ślokas are devoted to the representation of the three aspects of the Word (associated here with the goddessmother Ambikā), which the meditator must learn. The goddesses Vāmā, Jyeșțhā, and Raudrī symbolize three energies and three stages of its "becoming". The initial stage is the stage Vāmā, when the word paśyantī, that is, the "visible", the visionary Word. At this stage, the principle of divine consciousness manifests itself with greater force, in which the image of the Word is the primary one and its visual and sound characteristics are synesthetically fused. Then comes the middle stage (madhyamā), which is personified by the goddess Jyeșthā and is called in the original text "jnānaśaktis" (the 'sakti of knowledge') - the Word is sorted by the elements. The word breaks up and an image of emptiness appears - bindu. So, having collapsed, the Word again clothed itself in the flesh and reaches the third stage, the densest one - in which words and objects "appear manifested" and are perceived separately. This threepart process, like the three vertices of a triangle, forms the triangular cakra closest to the center of the the śricakra or the śriyantra in "Fig. 2".

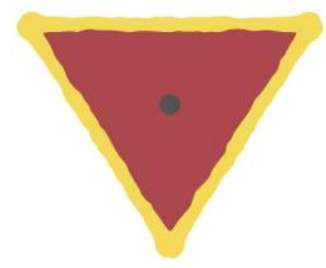

Fig. 2. Diagram of the central triangle of the śricakra, with bindu-dot in the centre, imitating the central fragment of the śriyantra in Fig. 1 above. 
In the ślokas of this Tantra, deities, in the form of geometric figures forming cakras, appear in various combinations of ten, nine, three, two, and each of them is thought of as a goddess symbolizing certain energy aspects of the universe; symbolically also the location of the triangles - closest to the empty initial point of the bindu (sanskrit 'Point'), to the center of yantra, triangles are located, and further - squares and circles in the form of lotuses. Squares (bhugrha 'house of the earth' from verbal root bhu 'to cause, to exist') in "Fig. 3" and the number of petals of the lotus also have a symbolic meaning.

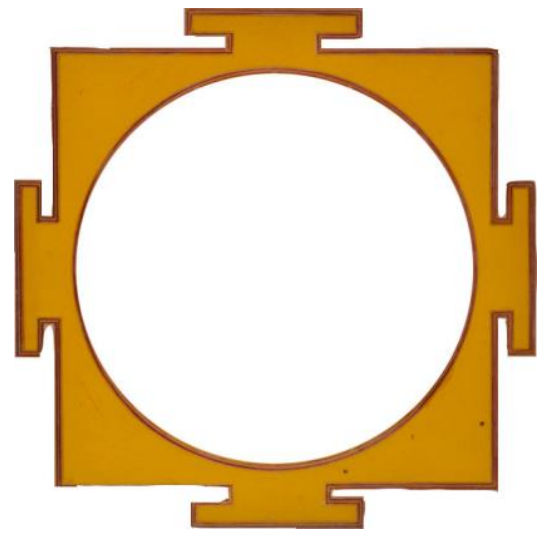

Fig. 3. Bhugrha

Yantra, as a collection of cakras, in this case, serves as a projection of the multi-level structure of the sacred text, a visual form of practical guidance on meditation that arose, it is believed, from some original image descended on a sage suddenly. In such a way magical diagrams appear - specific Tantric mandalas ${ }^{5}$ - which are, as it is possible to say, symbolic representations of the human body and, at the same time, the divine universe similar to it. A coloured geometric pattern unfolding from an invisible "empty" center, contains symbols, repeated a certain number of times, and in general it can be said that triangles point to female nature, yoni (Sanskrit 'female sexual organ') and śakti - the source of the highest universal energy, squares can be associated with the earth (bhūgrha), or with the manifestation of the world, lotuses (for example, eight-petalled, sixteen-petalled, etc.), depending on the number, can perform different functions [8]. These symbols are inextricably linked with the male principle - the lingam, personified in the image of the god Siva.

The concept of corporeality in the Tantra doctrine of liberation, understood as a view on the structure of the human body and the divine body of the universe, which are of a similar nature, and also the features of the category of space emanating from these relationships, may have different characteristics depending on one or another tradition, but in general, rest on the ancient Indian tradition dehatattva (deha — 'body', tattva — 'a true principle') [9]. What unites the

Mandala (Sanskrit 'Circle') - "symmetrical symbolic drawing of being-in-the-world", oriented along the sides of the world and reflecting the structure of the cosmos as a connection between the individual soul and the universe [7]. various traditions associated with Tantra, is the realization of oneself as an individual not only as part of a great whole, but as the very manifestation of a higher principle. As proclaimed in one of the Tantric texts of the Kartābhajās school, studied by Hugh Urban:

Tantric corporeality thought exists in the context of the general Indian conceptual structure, the main feature of which is micro-macrocosmic correspondence, hierarchical ideas about the structure of the cosmos, where the person purușa - is represented as a set of connected shells (atmans), distinguished by "fineness" and "hardness". At the same time, the lower the density this shell has, or the greater the inaudibility, the greater the non-manifestation, the less hardness, the better and higher the hierarchy it is. Through these "thin" shells the contact with the universal consciousness occurs, the various forms of which manifest the energies associated with the gods or goddesses. Also, there are channels nādīs, connecting energy centers - cakras.

The body of the individual gets into the focus of Tantra as the depository for the cosmic energy ${ }^{6}$ (kundalinī), which can be actualized or awakened through certain practices meditations (bhāvanā or dhyāna). Man, puruṣa or manuṣa, refers to the body - microcosm, the Absolute (Brahma) - to the macrocosmic body (the universe is represented as the "egg of Brahma", hiranyagarbha). The peculiarity of Tantric thinking of the body consists only in the point of view - as it were "from below", when the opportunity to connect with the Absolute is presented through the microcosmic tool - the body. At the baseline of the coarsest body shell (annamaya) there is the energy, therefore essentially there is no difference between the matter and spirit, it is given only in degree.

This concept of corporality is radically different from the post-Cartesian European philosophy, where there is a gap between the mental and physical world, as V. G. Lysenko points out in her work [12]. This view helps to perceive the entire space of the world as a single mystical body: the individual body for tantrics becomes the image of a phenomenal world through which Brahman (the Absolute, the universe) communicates with the individual essence - the Atman.

\section{INDIAN MODERN ARTIST JAGDISH SWAMINATHAN}

A great impact on artists seeking to develop principles for the creation of a special, national Indian Modernism (P. T. Reddy, G. R. Santosh, Biren De, Om Prakash, S. H. Raza and others) had Mulk Rāj Ananda's (1930) and, subsequently, Ajit Mookerjee's (1971) works that constitute the body of so-called Neotantric texts ${ }^{7}[13]$.

\footnotetext{
6 Cf.: "The human body, with its psychological and biological functions, is a vehicle through which the dormant psychic energy, Kundalinī Śakti, can be awakened to finally unite with the Cosmic Consciousness that is Śiva" [11].

Also, it is necessary to mention the works by Aurobindo Ghosh, a religious figure of the first half of the 20th century, who developed in his works the concept of Śakti and founded an ashram in Pondicherry
} 
The main pathos of Indian Neotantrism ${ }^{8}$ was that modern achievements in the exact sciences, perceived as an integral part of the modernized Eurocentric civilization, had long been known to Indian Tantric mystics. For example, the fact that both sound and colour, according to the data of modern physics have the same - wave - nature, in Neotantrism, was predicted by the fact that the mantra (oral, pronounced formula, i.e. sound) and yantra (the visual equivalent of this formula) are similar. The idea that the modern view of the world was foreseen in the distant Indian antiquity, inspired those artists and thinkers who were raised on the idea of the hegemony of Western values, but sought to free themselves from its oppression.

One of these artists was Swaminathan, in whose paintings, in the 1960 s, images appear inspired directly by Tantric mysticism. They reflect the concept of the global coherence of things in the universe and the fact that the human body is inscribed in its structure.

Jagdish Swaminathan (1924-2002), a modern Indian artist, who lived and worked in New Delhi, is widely known in India and abroad due to the picture series "Bird, Tree and Mountain", in which the traditional cosmological image of the world mountain and the growing world tree that connects the three worlds was played out in "Fig. 4".

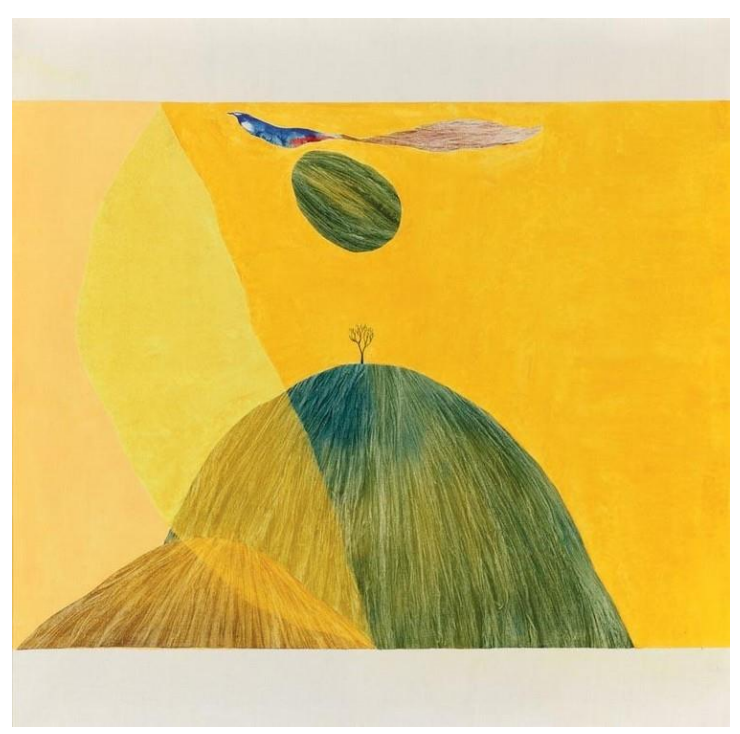

Fig. 4. J. Swaminathan, Untitled from Bird, Tree and Mountain series, 1974.

The key Tantric symbols appears in his works from the early 1960's. For example, in the picture of the 1963 year (Figure 5), the plane of the canvas is divided into three segments, each containing a specific symbol. In the left part,

8 The Indian and Western Neotantrism are historically connected, but it is worthwhile to distinguish them. The first is associated with a new interpretation of the Tantra texts in the 1930s, and later manifested itself in the modernist art of India. The second spread in the USA and Europe as early as the $1960 \mathrm{~s}$, is associated with the commercialization of ritual practices that went contrary to the fact that in the original Tantric sects, knowledge could only be transferred to the disciple from the initiating guru within the framework of a specific relationship based on the idea of bhakti (Sanskrit 'devotional service'). almost Van Gogh's sun with representative strokes, transmitting the movement of the light; in the right, the trident of Siva; between them, in the square, a deliberately ambiguous image is placed - a rounded red yoni emitting light, which also looks like a seed (the traditional yoni / lingam image is equally ambiguous). This image, placed on a blue-red background, symbolizes the two-faced nature of any wholeness, the duality of the being, including both feminine and masculine, like prakṛti (Sanskrit 'cause, matter, female element'), and purusa (Sanskrit 'man') ${ }^{9}$. In the bottom, this segment is edged with a less evident, but readable images triangles, a spiral, a snake, and a seed. In this work, the artist seeks to convey vibration, the wave movement of kundalinī (ascending psychic energy), using the sand applied to the oil or wax base of the canvas: the frozen sand on the plane seems to reproduce the ritual circular movements of the hands and, according to Geeta Kapur, "turns it into the movement of the signifier through an iconic image" [14].

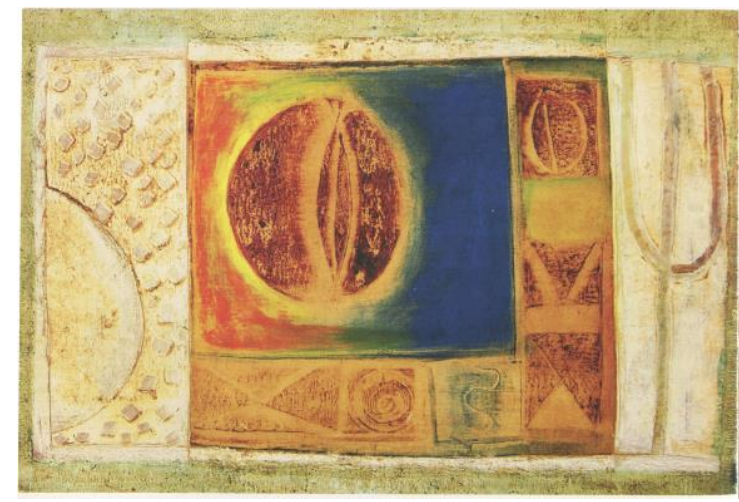

Fig. 5. J. Swaminathan. Untitled, 1963.

The seed depicted in the centre of the composition (bija) symbolizes the beginning or the cause of all things, enclosed in an energy cluster that carries in it the germ of a two-part whole. In this sense, the bija is related to the concept of bindu - the original "empty" cosmic point devoid of any form. The Tantric tradition connects the birth of the universe with the appearance of fifty bija mantras (the number of signs in the Devanagari alphabet), the "seed syllables" or primary sounds - certain combinations (for example, Om, Hrim, Ram etc.) carrying the mystical meaning and associated with certain deities and yantras, with their geometric and colour equivalents, used as meditational and ritual instruments in Hindu Tantrism (as was discussed above in the part I of the article) [15].

By 1966, Swaminathan's artistic style has undergone significant changes: he refuses to use Tantric symbols directly (snakes, seeds, lotuses and others). According to Swaminathan, other symbols - geometric forms - are "clothed" in them [16]. So he refers to the abstraction: geometric figures, filled with colour, appear in his works (Fig. 6). In the catalogue for the exhibition Color and Geometry of Space he writes, "... I became conscious of the

In the Sankhya philosophy, prakriti is treated as the material source of the universe, the female element, which comes into contact with the male element, purusa. 
need for isolating and studying this geometry ... Is this geometry a mere compositional device, or is it capable of generating a mystical dimension?'[17]. Geeta Kapur, in her critical note about this exhibition, explains that Tantric symbols have magical properties - with their help the viewer can achieve the maximum of inner concentration and find a mystical unity with the whole world [18].

Tantric idea of the similarity of small and great, the comprehension of space through the human body, which was discussed in the first part of this article, is a striking feature of Swamintahan's art. He reinterprets the process of creation an art work as a mystical practice which is an analogous to various Tantric rituals. In the manifesto of 1963, written by Swaminathan for the "Group of 1890" (the artistic association leaded by him), he writes: "To us, the creative act is an experience in itself, appropriated by us and therefore bearing no relation to the work of art, which creates its own field of experience as the experience of copulation is not the same as that of the offspring, a work of art has to be experienced, the experience not being subject to judgment or assessment" [19].

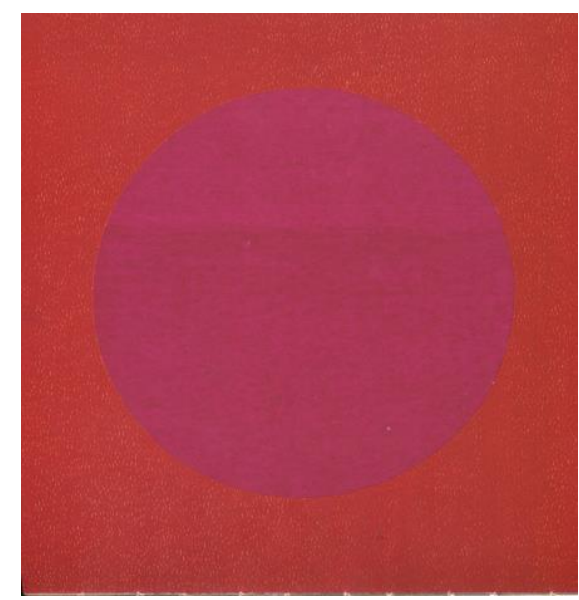

Fig. 6. J. Swaminathan. Untitled, 1964. In this image Swaminathan reinterprets the image of the base layer of yantra — bhūgrha in Fig. 3.

In the accompanying text for the exhibition Colour and Geometry of Space (1966), Swaminathan quotes perhaps the most famous mantra, the Santi-mantra (Sanskrit "mantra of rest"), which precedes the early î́sa Upanișad [20] [21]:

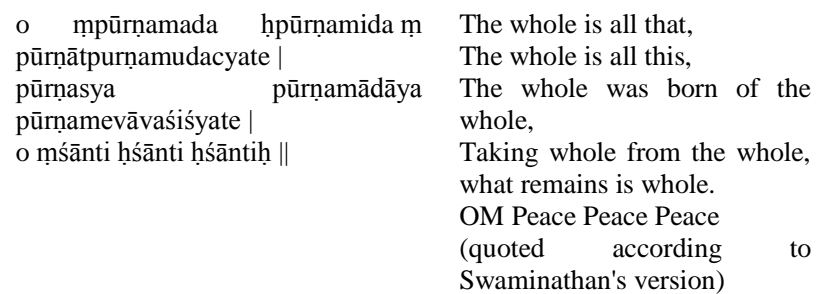

iśa Upanișad considers the possibilities of human cognition and the path to the true knowledge (Sanskrit jñāna, akin to the ancient Greek $\gamma v \tilde{\omega} \sigma 1 \varsigma$ - 'gnosis $\left.{ }^{10}\right)$. The repetition

10 For more on comparing the Indian concept of jñāna and Greek gnosis, see. Pakhomov S.V. Soteriologicheskoe znanie v induistskom tantrizme [Soteriological knowledge in Hindu Tantrism], 2015, pp.142-143 [22]. of the word pūrna (Sanskrit 'full') in the Upanishad mantra that precedes this Upanishad is intended to express the universal fullness of the Absolute, to represent space as one and "unmanifested" (avyaktam) ${ }^{11}$. Swaminathan uses the concepts of the "unmanifested" to compare the Indian and European cultural paradigms: he argues that space cannot be studied by analytical methods (as in the European paradigm), but one can correlate oneself with the basic characteristic of space - its non-manifestation - with geometric colour forms, such as a triangle, a square and a circle that become some kind of "windows" in the "unmanifested" spaces, in avyaktam [23].

In polemic texts, Swaminathan often refers to the concept of analytism, which refers to the method of European art, which is by no means connected with the analytical art of Pavel Filonov and his method of "organic" cultivation of a picture from cubistic fragments of an image. He has in mind the method that arose in India under the influence of the colonial situation and concentrated all the attention of Indian artists on mastering "technology" in isolation from "content" ${ }^{12}$. Analyzing the European history of art and explaining the reason for the appearance of such "constructivism", the artist writes: "The analytical realism of the Western approach led it to question successive modes of pictorial representation. The movement which started as a revolt against the Renaissance tradition started by questioning the various components of pictorial representation and not pictorial creation. So, we have the painter moving away from Naturalistic representation to Impressionistic representation, from Impressionistic representation to Expressionistic representation, from Expressionistic representation to Cubism, from Cubism to Surrealism as the representation of the other reality and so to Abstraction as a flight from reality, and therefore inexorably bound to it. The return to the mundane in Pop art is but the completion of the cycle [24].

Thus, the idea of the discreteness of space that can be constructed, built or broken, is opposed to the idea of the totality of Indian art, based on the religious and philosophical tradition, where space is immanent and sacred: it already exists as a given, and has properties that can be actualized and acquired through the divine geometry of yantra.

The concept of pūrṇa pūrṇatā ('fullness') in the Tantric tradition is one of the main ideas of the divine fullness of being. This fullness is formed by the sacred union of Śiva and Śakti, identical to each other up to the condition of nondistinction, connecting all the necessary elements of the universe in absolute form. It is this concept that is expressed by a diagram in which they converge in the empty center (kha, bindu) from the outer figure of the square (the "coarse" form itself) to the inner triangles (the more "subtle" types of energy).

12 Perhaps one of the few European artists whose work was relevant to Swaminathan's is Paul Klee, perceived by him as an artist of the mythological type, who expressed "the mystery of life itself". The influence of Klee is also noticeable in the work of the Madras artist K. C. S. Paniker. 


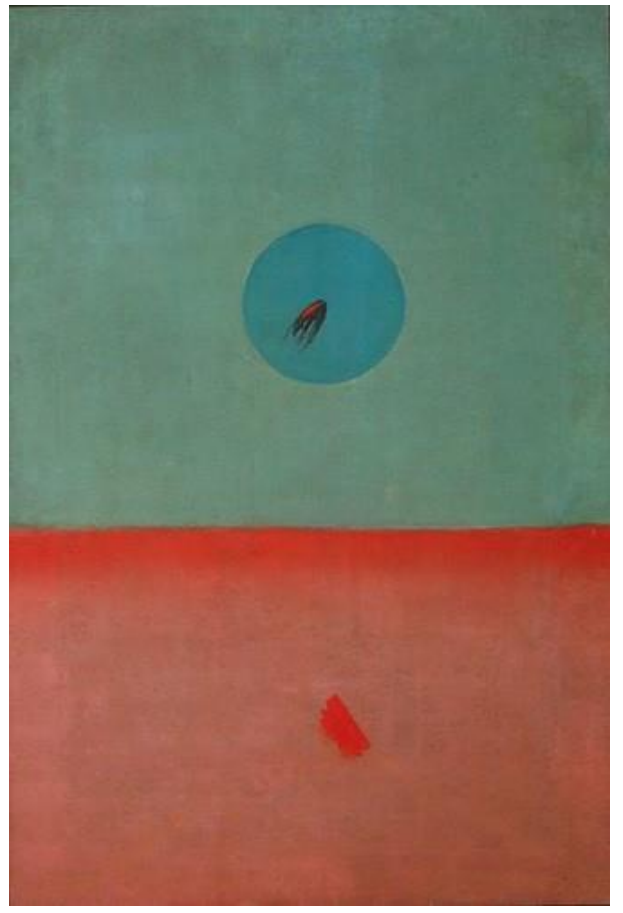

Fig. 7. J. Swaminathan. Untitled, 1964.

In one of the pictures of the series Colour and Geometry of Space (Figure 8), one can see the image of the bija and refer to the idea of two aspects of being (passive and active, male and female, purușa and prakrti), which, together with each other, form a unity.

\section{CONCLUSION}

In the first part of the article we discussed the corporeality concept reflected in Tantric Thought and its specific synesthesia of visual (yantra) and vocal (vāc, mantra) imagery that unites a human with cosmos.

The problem of this kind of corporeality is more or less relevant when considering the art of Indian modernism. J. Swaminathan was experimenting with geometrical forms using Tantric painting and learning "the function of colour as geometry in creating infinite, total space, the anthropomorphic imagination", as he put it [25].

All the compositions of the geometric series in question are abstract, but they trace the leading "yantric" idea. Applying to the series, one can speak of a specific way of understanding corporeality as a universal humanistic and anthropomorphic category, realized as a magic formula designed in a modernistic way to absorb the Other in the face of colonial European art, and in the whole to overcome its "analitism" and the gap between mental and physical aspect.

Borrowed from the fine instruments of the Tantric tradition, symbols lose their ritual function, turning into pure geometric forms and becoming part of the easel painting, which in turn returns the viewer to the mystical world of the ritual.

\section{REFERENCES}

[1] S. Pakhomov, Genesis of Hindu Tantrism, part 1 // IX Sociological Reading for Lecturers, Aspirants and Students. Interacademic Corpus of Scientific Papers, 2007, pp. 126-141.

[2] S. Pakhomov, Genesis of Hindu Tantrism, part 2] // X Sociological Reading for Lecturers, Aspirants and Students. Interacademic Corpus of Scientific Papers, 2008. pp. 257-266.

[3] S. V. Pakhomov, The problem of correlation of ethics in yoga and hindu tantra. Shabdaprakasha. Zografs corpus, 2011, vol. 1, pp. 126137.

[4] T. Ja. Elizarenkova, The language and the style of the vedic rishi. Abstract of Ph.D. dis., Moskva, 1993, p. 7.

[5] H. B. Urban, The Economics of Ecstasy. Tantra, Secrecy, and Power in Colonial Bengal. New York, 2001, p. 143.

[6] Cit. ex, p. 68.

[7] A.V. Paribok, Mandala, Indian Philosophy. Encyclopedia / Ed. M.T. Stepanjanc, Moscow, 2009, p. 503.

[8] S. Pakhomov, Tantrism. Indian Philosophy. Encyclopedia / Ed. M.T. Stepanjanc, Moscow, 2009, pp. 771-774.

[9] A. Padoux and R.-O. Jeanty, The Heart of The Yoginī: The Yoginīhrdaya, a Sanskrit Tantric Treatise. New York, 2013, p. 31.

[10] Ibid., p. 38.

[11] A. Mookerjee and M. Khanna, The Tantric Way. Art. Science. Ritual. London, 1977, p. 21

[12] V. Lysenko, The Subject of "a Living Body" in the History of Philosophy]. Moscow; Saint Petersburg, 2016, pp. 43-65.

[13] M.R. Anand, The Hindu View of Art. Bombay, 1957.

[14] G. Kapur, J. Swaminathan: The Artist the Ideologue the Man His Persona // Lalit Kala Contemporary. 1995. № 40 (Special Issue on J. Swaminathan), pp. 61-62.

[15] A. Mookerjee, Tantra Art in Search of Life Divine. Lalit Kala Contemporary. 1971, No. 12-13, pp. 8-10.

[16] J. Swaminathan, Color Geometry (Catalogue of Exhibition, 1967). Lalit Kala Contemporary, 1995, No. 40 (Special Issue on J. Swaminathan), p. 21.

[17] Ibid.

[18] Transits of a Wholetimer. J. Swaminathan: Years 1950-1969. New Delhi, 2012, p. 86.

[19] Ibid., p. 70.

[20] The Principal Upanișads / Ed. and transl. by S. Radhakrishnan. London, 1968, p.564.

[21] J. Swaminathan, Color Geometry (Catalogue of Exhibition, 1967). Lalit Kala Contemporary, 1995, No. 40 (Special Issue on J. Swaminathan), p. 21.

[22] S.V. Pakhomov, Soteriological knowledge in Hindu Tantrism, 2015, pp. $141-150$

[23] Transits of a Wholetimer. J. Swaminathan: Years 1950-1969. New Delhi, 2012, p. 80.

[24] J. Swaminathan, The New Promise. Lalit Kala Contemporary, 1995, No.40 (Special Issue on J. Swaminathan), pp. 18-20.

[25] J. Swaminathan, The Cube and the Rectangle. Lalit Kala Contemporary, 1995, No. 40 (Special Issue on J. Swaminathan), pp. 21-23. 